\title{
Who's in power matters : System justification and system derogation in Hungary between 2002 and 2018
}

\section{Szabo, Zsolt Peter}

$2021-10$

Szabo , Z P \& Lonnqvist, J-E 2021, ' Who's in power matters : System justification and system derogation in Hungary between 2002 and 2018 ', International Journal of Psychology , vol. 56 , no. 5 , pp. 679-687 . https://doi.org/10.1002/ijop.12747

http://hdl.handle.net/10138/340237

https://doi.org/10.1002/ijop.12747

cc_by_nc

acceptedVersion

Downloaded from Helda, University of Helsinki institutional repository.

This is an electronic reprint of the original article.

This reprint may differ from the original in pagination and typographic detail.

Please cite the original version. 


\section{POWER SYSTEM JUSTIFICATION RIGIDITY}

\section{Abstract (157/200)}

The present study employed ESS data collected between 2002 and 2018 to investigate system justification vs. derogation in Hungary. In all nine ESS rounds, system derogation was stronger than system justification. System justification was consistently at its strongest among those who had voted for the ruling party, be it left-wing MSZP (until 2008) or right-wing Fidesz (2010 onward). This pattern can be explained by ego and group justification motives alone, with no need to posit an autonomous system justification motive. The above pattern also questions the rigidity-of-the-right hypothesis. Drawing further doubt on this hypothesis, voters of Jobbik, who were as right-wing as Fidesz voters, but whose party was not in power, did not believe the system to be any more just than did left-wing voters. Much of the research supporting system justification theory and the rigidity-ofthe-right hypothesis has been conducted in stable Western democracies. Our results highlight the need for research in more politically volatile contexts.

Keywords: system justification; rigidity-of-the-right; system derogation; left-right; political attitudes

\section{Introduction}

The Hungarian political scene is turning out to be fruitful testing ground for political psychology theory. The present paper focuses on two issues regarding which the results appears inconsistent. First, controversy has emerged on the question of system justification vs. system derogation. According to system justification theory, people are motivated to defend, bolster, and justify aspects of existing social, economic, and political systems (Jost, 2019). System justifying beliefs are argued to satisfy epistemic, existential, and relational needs. The theory of system justification has been consistently supported by data obtained in several Western contexts, but data collected in Central and Eastern European post-socialist countries has supported system derogation; that is, a negative attitude towards the status quo (Cichocka \& Jost, 2014; Kelemen et al., 2014). More recently, however, Jost and Kende (2020) examined the results of two large-scale studies run in 


\section{POWER SYSTEM JUSTIFICATION RIGIDITY}

Hungary and did not find empirical support for system derogation. This issue of system justification versus system derogation can be connected to a broader theoretical debate between proponents of system justification theory and social identity theory regarding the existence of an autonomous system justification motive. Recently social identity theorists (Owuamalam, Rubin, \& Spears, 2018, 2019a, b; Caricati \& Owuamalam, 2020) argued that ego and group justification can fully account for system justification tendencies (cf. Jost et al., 2019). Examining this debate in the Hungarian context, in which the shifts in the balance of power have been acute and have had major ramifications, could be especially illuminating, particularly as previous work in Hungary has revealed both system justification and system derogation tendencies. How these tendencies respond to who is running the country-one's own party or its rival party-could contribute to the debate regarding the existence of an autonomous system justification motive. The presence of system justification tendencies only among those whose party is in control would suggest that ego and group justification by themselves could be sufficient to explain system justification tendencies.

The second controversy on which we focus and for which the Hungarian contexts could provide an especially illuminating case study is the controversy surrounding the rigidity-of-the-right hypothesis. As has been the case for the inconsistent findings on system justification and system derogation, studies run in Hungary have also reported on inconsistent findings regarding the rigidityof-the-right hypothesis. This hypothesis suggests that a right-wing (as opposed to left-wing) political orientation is associated with higher levels of cognitive and perceptual rigidity, dogmatism, and intolerance of ambiguity, along with stronger needs for order, simplicity, structure and closure (Jost, 2017). However, recent studies have argued that liberals and leftists can be as rigid as conservatives and those on the political right (e.g., Conway III et al., 2018; Zmigrod, Rentfrow, \& Robbins, 2019). In line with these findings, Lönnqvist, Szabó and Kelemen (2019) showed that in a representative Hungarian sample, voters of a radical right-wing political party (Jobbik) scored higher than voters of other parties on the Need for Cognition Scale, and lower on measures of global belief in a just world and system justification. This was, however, followed by a study in which Jost and Kende (2020) 


\section{POWER SYSTEM JUSTIFICATION RIGIDITY}

provided empirical support for the rigidity-of-the-right hypothesis in a Hungarian context.

Specifically, self-placement as politically right (vs. left) was associated with higher scores on need for order and structure and on system justification (see also Caricati, 2019).

The present study sought to address the above inconsistencies employing data obtained in the first nine rounds of the European Social Survey (ESS). Specifically, we focused on the prevalence of system justification (vs. derogation) tendencies, and on whether either self-placement as politically right (vs. left) or voting for right-wing (vs. left-wing) parties was associated with system justification. We focus especially on variation over time, as the above referred to apparently inconsistent results are based on data sets collected at different time points that have varied greatly in terms of political context.

\section{The Hungarian Context}

In 1989, the Third Hungarian Republic was established in parallel with the collapse of the Soviet Union. The initial enthusiasm for democracy and capitalism soon withered away with the emergence of serious problems: the national economy came to the verge of collapse. In 1994, MSZP (Hungarian Socialist Party) won a two-thirds majority in the parliament. The socialist government lost the 1998 national elections, and the Fidesz party (Federation of Young Democrats) received mandate to form government. The left-wing MSZP won the elections again in 2002 and then in 2006. However, the second term of the governing party started with an ominous event in 2006 . One month after the elections, an anonymous source publicly disclosed an audio-recording of a closed faction meeting, at which Prime Minister Ferenc Gyurcsány declared that he and his party had continuously lied to their voters over the past one or two years. The leaked recording elicited a wave of protests (Benczes, 2016). The scandal-torn governing party, having lost around one fifth of its voters, was ultimately swept off of the political arena by the outbreak of the global economic crisis in 2008. Fidesz won a two-thirds majority in the 2010 national elections, and repeated this in 2014 and 2018. In sum, the left-wing social democratic MSZP was in power from 2002 until 2010, after which its conservative 


\section{POWER SYSTEM JUSTIFICATION RIGIDITY}

rival Fidesz has ruled. The third major player has been the radical right-wing Jobbik party (Movement for a Better Hungary). They formed a party in 2003 , and won their first seats in the national parliament in 2010, ranking as the third most popular party, and holding its steady share of votes in 2014 and 2018. Over the past years, Jobbik has shifted towards a more moderate centre-right position.

The above cited studies reporting on apparently inconsistent (Caricati, 2019; Jost \& Kende, 2020; Kelemen et al., 2014; Lönnqvist et al., 2019) results employed data sets collected in very different political and economic contexts. Kelemen and colleagues (2014) collected data one month before the fall of the left-wing social democratic MSZP in 2010, which coincided with the climax of the global economic crisis, and these data were subjected to a secondary analysis by Lönnqvist and colleagues (2019). By contrast, Caricati (2019) and Jost and Kende (2020) based their finding on data collected in a globally stable economic situation, during which a right-wing government held power in Hungary. The ESS data that we employ allows us to investigate these political developments can help explain the apparently disparate results.

\section{System Justification and Rigidity-of-the-Right in the Hungarian Context: An Overview of Existing}

\section{Empirical Findings}

Kelemen and colleagues (2014) analyzed a representative dataset obtained in 2010, which was subjected to a secondary analysis by Lönnqvist and colleagues (2019). Pertinent to the present research, Kelemen and colleagues (2014) reported that Hungarian respondents generally showed system derogation (vs. system justification). The authors measured system justification with a 5-item short version of the 8-item scale proposed by Kay and Jost (2003), and each item was rated on a 4point scale. The mean value obtained for the overall sample was well below the scale midpoint $(M=$ $1.84, S D=0.50)$. The secondary analysis conducted by Lönnqvist and colleagues (2019) revealed significant differences in system justification and need for cognition between groups of voters (see Table 1; Lönnqvist et al., 2019). Specifically, Jobbik voters scored significantly lower on system 


\section{POWER SYSTEM JUSTIFICATION RIGIDITY}

justification $(M=1.66, S D=0.47)$, than did Fidesz $(M=1.83, S D=0.47)$ or $\operatorname{MSZP}(M=1.97, S D=0.56)$ voters, whilst scoring higher on need for cognition $(M=2.86, S D=0.63$ for Jobbik voters, $M=2.66$, $S D=0.62$ for Fidesz voters, and $M=2.52, S D=0.62$ for MSZP voters). Given that Jobbik was at the time a radical-right party, the authors argued that the results for Jobbik (low system justification, high need for cognition) were inconsistent with the rigidity-of-the-right hypothesis. Our results dovetail with recent findings showing that leftists can also be high in dogmatism, prejudice and attitude strength depending on the questions researchers asked (rigidity-of-the-left hypothesis, also known as the authoritarianism symmetry hypothesis; Conway III et al., 2018)and the intensity of their partisanship (rigidity-of-the-extreme hypothesis; Zmigrod et al., 2019)

The findings reported by Jost and Kende (2020) tell a different story to the one above. They conclude, on the one hand, that the Hungarian context is not characterized by wide-spread system derogation, and, on the other hand, that Hungarian data does support the rigidity-of-the-right hypothesis. The first conclusion is based on data obtained with a measure of general system justification administered to a nationally representative sample in 2014 and with general and economic system justification measures administered to a non-representative sample in 2017. The second conclusion, regarding the rigidity-of-the-right hypothesis, was tested by correlating in both the 2014 and 2017 samples system justification with self-placement on a single-item left-right scale and with party preference. Participants' personal need for order and structure was also measured in 2014. Regarding system justification vs. system derogation, the Study 1 sample scored 2.24 (SD = 0.80) on a 5-point scale measuring system justification, and the Study 2 sample scored 3.40 (SD = 1.72 ) and $4.15(S D=1.72)$, on two 9-point scales measuring general and economic system justification, respectively. Despite these means all being somewhat or far below the midpoints of the scales, Jost and Kende (2020) "saw no evidence that Hungarian respondents were extremely 'systemderogating', as Kelemen et al. (2014) argued" (p. 105). Also noteworthy is that voters of all other parties than Fidesz (in rule at the time) showed extremely low mean scores on general system justification (i.e., only Fidesz voters' mean score was higher than 3 on the 9-point scale). Regardless 


\section{POWER SYSTEM JUSTIFICATION RIGIDITY}

of how these results best be described, the results are consistent with those of Kelemen and colleagues (2014) in the sense that the majority of Hungarians were more prone to disagree than to agree with system-justifying beliefs, and that this was particularly true of those who did not support Fidesz.

Regarding the rigidity-of-the-right hypothesis, Jost and Kende (2020) found that selfplacement on the right was positively correlated with all system justification measures in both studies, and also with personal need for order and structure, when controlling for interfering factors. Specifically, in the 2014 sample, the correlation was $r=.369$ and in the 2017 sample the correlations were $r=.312$ and $r=.093$ (all $p<.001$ ), for general and economic system justification, respectively. Moreover, in the previous sample, self-placement to the right was weakly correlated with personal need for order and structure $(r=.093, p<.001)$. Party preference was only assessed in the 2017 sample, in which Fidesz supporters scored higher on both general and economic system justification than anyone else. The rigidity-of-the-right hypothesis was also supported by Caricati (2019), who in Hungarian data from 2016 also found a significant positive correlation between right-wing political orientation and system justification. Jost and Kende (2020) thus concluded that "Rightists in Hungary -as in Italy and the U.K. and many other countries- are indeed more cognitively rigid, more prejudiced and intolerant, and more system-justifying both in general and with respect to the current economic system than are their counterparts on the left" (p. 112).

\section{Research Aims}

The present study employed the nine rounds of ESS data collected between 2002 and 2018 to address two issues. First, we sought to investigate system justification vs. derogation in Hungary from 2002 to 2018. The existing theories and empirical findings allow for two contrasting hypotheses. Based on system justification theory, we would expect system justification not only among those whose party is presently in power, but also among supporters of the rival parties. By contrast, based on the social identity theory framework, which postulates only ego and group 


\section{POWER SYSTEM JUSTIFICATION RIGIDITY}

justification motives, and not an autonomous system justification motive, one would expect system justification to be present only among supporters of the ruling party.

Second, we sought to investigate the rigidity-of-the-right hypothesis; more specifically, we investigated whether left vs. right self-placement, and/or party support, is associated with system justification. Here, the existing theories and empirical findings also allow for two contrasting hypotheses. Based on the rigidity-of-the-right hypothesis, we would except that those on the political right show more system justifying tendencies regardless of the ruling party. By contrast, recent work suggesting the rigidity-of-the-left and the rigidity-of-the-extreme would suggest that both those on the (far) left and on the (far) right can be as likely to justify the system, depending on the political context; i.e., who is in power.

\section{Study}

\section{Databases and Participants}

We employed data from the first nine rounds of the ESS, conducted every other year between 2002 and 2018. Participants missing relevant data were excluded. The most important demographic data and the number of excluded participants are shown in Table 1.

\section{Measures}

System Justification-Satisfaction and Trust. Following Caricati (2019), system justification was measured both as satisfaction with "apolitical" aspects of the existing social system and as personal trust in certain national institutions (see also Brandt, 2013; Jost et al., 2003). Satisfaction with the system was measured with four items pertaining to the prevailing social order. These items were : "On the whole how satisfied are you with the present state of the economy in Hungary?"; "On the whole, how satisfied are you with the way democracy works in Hungary?"; "What you think overall about the state of education in Hungary nowadays?"; and "Say what you think overall about 


\section{POWER SYSTEM JUSTIFICATION RIGIDITY}

the state of health services in Hungary nowadays". Participants rated each item on an 11-point scale ranging from extremely dissatisfied or extremely bad (0) to extremely satisfied or extremely good (10). Our measure of overall satisfaction with the system was the average of the four items. The internal consistency of the scale (Cronbach's $\alpha$ ) varied between .69 and .87 across the nine survey rounds. Personal trust in national institutions was measured with five items (i.e., trust in the national parliament, the legal system, the police, politicians, and political parties) ${ }^{1}$. Participants rated each item on an 11-point scale ranging from no trust at all (0) to complete trust (10). Our measure of personal trust was the average of the five items. The internal consistency of the scale (Cronbach's $\alpha$ ) varied between.84 and .92 across the nine survey rounds.

Left-Right Self-placement and Partisanship. Left-right self-placement was assessed with an 11-point. The instructions were: "In politics people sometimes talk of "left" and "right". Using this card, where would you place yourself on this scale, where 0 means the left and 10 means the right?" Participants' indicated their party preferences by responding to the item: "Which party did you vote for in the last election?"

\section{Results}

The issue of system justification vs. system derogation was investigated in the overall samples and in different groups of voters. The rigidity-of-the-right hypothesis was examined in two ways. First, by correlating left-right self-placement with system justifying beliefs. Second, by using general linear models (GLMs) in which participants' gender and age were entered as control variables to test for differences in system justifying beliefs between different groups of voters. Table 2 shows the descriptive statistics obtained for the overall sample and for the subsamples consisting of Fidesz, Jobbik, and social democrat voters (only participants who reported having voted for one of these three parties were included in the GLMS).

[INSERT TABLE 2 HERE] 


\section{POWER SYSTEM JUSTIFICATION RIGIDITY}

Table 2 shows that satisfaction with the system remained below the midpoint of the 11-point scale in all nine ESS rounds, ranging from 3.31 to 4.80 . In 3 out of the 9 rounds, satisfaction was below 4 . In every round, those who had voted for the party that was currently in power had higher scores on satisfaction, whereas those who had not almost without exception scored below 4 . Table 2 also shows a similar pattern for personal trust in national institutions. Personal trust remained below the midpoint of the 11-point scale in every ESS rounds except 2018, ranging from 3.01 to 5.04. In 3 out of the 9 rounds, trust was below 4.

Regarding the rigidity-of-the-right, Table 3 shows the correlations between left-right self-placement and system justifying beliefs across time. These correlations show that from 2004 to 2008, when MSZP was in power, those to the left were more inclined to believe in the system. That pattern reversed in 2010, when Fidesz took over. Since then, those to the right have been more inclined to believe in the system.

[INSERT TABLE 3 HERE]

We also assessed the rigidity of the right by means of GLMs. From 2012 onward, the data included both Jobbik and Fidesz voters. Both parties are to the right in the political spectrum, and as their relative positions may be consequential for interpretation, we started by assessing their voters' standing on the left-right scale. In 2012 and 2014 Jobbik voters were significantly closer to the right pole $(M=7.45, S D=1.94$ in $2012, M=7.39, S D=2.02$ in 2014 for Jobbik voters, and $M=6.57, S D=$ 1.94 in 2012, $M=6.70, S D=1.97$ in 2014 for Fidesz voters; $p<.001$ in both years). In 2016, there was no significant difference between Jobbik and Fidesz voters $(p=.92)$. In 2018, Fidesz voters were further to the right $(M=6.86, S D=2.49$ for Fidesz voters, and $M=6.06, S D=2.78$ for Jobbik voters, $p$ $=.005)$. The year-to-year differences cancelled each other out, and no significant differences were found when compiling the 2012 to 2018 data $(p=.22)$.

A GLM with system-justifying beliefs as the dependent variables was ran for each ESS round. Voting behavior in the last national elections was the predictor variable, and age and gender were 


\section{POWER SYSTEM JUSTIFICATION RIGIDITY}

covariates. The results showed significant differences between the three subsamples of voters. In 2002, no significant difference was found between MSZP and Fidesz voters in satisfaction with the system $(F(1,801)=1.55, p=.21)$, but personal trust was significantly different $(F(1,801)=6.74, p=$ .010).

In 2004, 2006 and 2008, MSZP voters scored significantly higher on both satisfaction with the existing system $(F(1,680)=20.18, p<.001$ in $2004 ; F(1,631)=86.34, p<.001$ in $2006 ; F(1,646)=46.56, p<$ .001 in 2008) and personal trust in national institutions $(F(1,680)=4.59, p=.03$ in $2004 ; F(1,631)=$ 46.08, $p<.001$ in 2006; $F(1,646)=17.45, p<.001$ in 2008) than did Fidesz voters.

In 2010, Fidesz voters scored significantly higher on both satisfaction and trust than either Jobbik voters or MSZP voters, while no significant difference was found between the latter two groups $(F(2$, $653)=19.91, p<.001$ for satisfaction, and $(F(2,653)=31.97, p<.001)$ for trust $)$. In 2012 , Fidesz voters scored significantly higher on both forms of system justification than either Jobbik voters or MSZP voters, and Jobbik voters scored significantly higher than MSZP voters $(F(2,795)=49.50, p<$ .001 for satisfaction, and $F(2,795)=29.80, p<.001$ for trust). In 2014, Fidesz voters scored significantly higher on both forms of system justification than either Jobbik voters or MSZP voters, while no significant difference was found between the latter two groups $(F(2,695)=66.43, p<.001$ for satisfaction, and $F(2,695)=42.29, p<.001$ for trust). In 2016, Fidesz voters scored significantly higher on both forms of system justification than either Jobbik voters or MSZP voters, and Jobbik voters scored significantly higher than MSZP voters in satisfaction,, but not in trust $(F(2,719)=$ $137.11, p<.001$ for satisfaction, and $F(2,719)=50.83, p<.001$ for trust $)$. In 2018, Fidesz voters scored significantly higher on both forms of system justification than either Jobbik voters or MSZP voters, while no significant difference was found between the latter two groups $(F(2,726)=197.83, p$ $<.001$ for satisfaction, $F(2,726)=122.52, p<.001$ for trust $)$.

\section{Discussion}




\section{POWER SYSTEM JUSTIFICATION RIGIDITY}

We employed nine rounds of ESS data, collected between 2002 and 2018 to investigate, first, whether Hungary is consistently better characterized by either system justification or system derogation, and second, whether voters of the Hungarian right can be characterized as more rigid than those on the left. Both questions have recently been subjects of intensive debate ( $\&$ Kende, 2020; Kelemen et al., 2014; Lönnqvist et al., 2019). We discuss the implications of our results for the theoretical debate on the existence of a system justification motive.

The literature on system justification has frequently faced and rebutted criticism suggesting that system-justification can contribute little, if anything, beyond the classic and generally accepted explanations offered by individual-level-justification (ego) and social-identity-based (group) justification (Jost et al., 2019; Owuamalam et al., 2019 a, b). According to Owuamalam, Rubin and Spears (2019a), "at the heart of the debate between system justification theorists (...) and social identity theorists (...) is whether an autonomous system justification motive is necessary to explain instances of system justification" (p. 393). In essence, both system justification theorists and their critics agree that system justification does happen, but critics argue that ego and group justification can explain it in full. Playing a pivotal role in this discussion is the claim, made by system justification theory, that members of disadvantaged groups are, because of the need to reduce cognitive dissonance, even more likely than advantaged groups to justify the system-this would imply that people justify the system without the presence of ego and/or group interests (Jost et al., 2003; van der Toorn et al., 2015). Critics (e.g., Owuamalam, Rubin, \& Spears, 2016; Owuamalam et al., 2019a,b; Caricati \& Owuamalam, 2020), on the other hand, have argued that system justification can be explained by group interest (e.g., the supporters of the ruling party are also the ones who justify the system) and/or individual interest (e.g., people with higher status are more willing to justify the system compared to people with lower status). Without an autonomous system justification motive, system justification theory can add very little to social identity theory. 


\section{POWER SYSTEM JUSTIFICATION RIGIDITY}

The results that we report on can be explained by ego and group justification motives alone. The only Hungarians to believe the system to be just were those who had voted for the party that was in power at the time the data was collected. Furthermore, there were stark differences between them and those who had voted of other parties (the data presented by Jost and Kende (2020) actually paints a very similar picture). Left-wing MSZP voters invariably showed the highest mean scores on system justification when MSZP was in power; that is, in 2004, 2006 and 2008. However, from 2010 onward, when Fidesz took over the government of Hungary, their supporters have believed far more strongly than anyone else in the system being just. In fact, across all nine rounds, only Fidesz voters in the last three rounds actually scored above the mean on satisfaction with the existing system, and only Fidesz voters in the last three rounds and MSZP voters in 2002 scored above the mean on personal trust in national institutions, indicating that system-derogation was extensive. Together these results suggest that there has been very little system justification happening in Hungary over the past two decades, and that the system justification that has occurred, as it has occurred only among voters of the party that has happened to be in power, can be fully accounted for by ego and group justification motives.

Besides questioning the existence of an autonomous system-justification motive, our results also question the rigidity-of-the-right hypothesis. First off, only after 2010, when the government became right-wing, did right-wing political orientation correlate positively with system justification. Prior to that, when MSZP ruled, right-wing political orientation was negatively correlated with system justification. Even more instructive is the comparison of Fidesz with Jobbik, the two largest parties since 2010. Voters of both parties are very far to the right, but only Fidesz has been in power. As noted by others, right-wing political orientation has in Hungary been correlated with system justification since 2010 (Caricati, 2019; Jost \& Kende, 2020). However, our results show that this correlation is driven solely by Fidesz voters, who greatly outnumber Jobbik voters. Jobbik voters are no more likely to justify the system than are left-wing voters (see also Jost and Kende, 2020, Figure 5, which shows that Jobbik voters have a mean level below 3 on a 9-point system justification scale, as 


\section{POWER SYSTEM JUSTIFICATION RIGIDITY}

compared to Fidesz voters with a mean level well above 5). That Jobbik voters do not believe in the system implies that it is not right-wing political orientation per se that is associated with system justification.

A long-standing line of work in political psychology emphasizes individual differences in basic psychological predispositions as the basis for political attitudes and behavior (Jost et al., 2009). In this bottom-up view, given that individuals are exposed to a sufficiently wide range of political ideas, these predispositions, such as needs for security and stability, are thought to guide individuals to adopt certain political preferences (Federico \& Malka, 2018; Feldman \& Johnston, 2014; Jost et al., 2009). One could thus have expected the associations between system-justifying belief and rightwing political orientation to be consistent across time. However, the variability that we observed points towards the role of the political context and, more specifically, power dynamics, in determining how motivated social cognition, such as system justification, is associated with political orientation.

Importantly, the results of the present study help understand the contradictions between the findings reported by Kelemen and colleagues (2014) and those reported by Jost and Kende (2020). Jost and Kende (2020) wrote that "although respondents did on average, score below the scale midpoint on both general and economic system justification measures, it would be an exaggeration to conclude that Hungarians today are "system-derogating", as Kelemen et al. (2014) argued" (p. 111). The most important words in that quote is "today" - the studies by Kelemen et al (2014; Lönnqvist et al., 2019) and Caricati (2019) and Jost and Kende (2020) were run in very different settings. Kelemen and colleagues (2014) reported on data collected in 2010 when MSZP was still in power, making the political context similar to that of the 2008 ESS data (the 2010 ESS data was collected later in 2010, after Fidesz had taken power). By contrast, Jost and Kende (2020) analyzed data collected in 2014 and in 2017. The ESS results show that overall system justification was actually lower in 2008 than in 2014 and in 2016, which suggests that the conclusions drawn by both research 


\section{POWER SYSTEM JUSTIFICATION RIGIDITY}

teams are valid to a certain extent. The 2006 and 2008 ESS data indicate that system justification was extremely low in Hungary, at least in part due to the leaking of a private speech delivered in 2006 by left-wing Prime Minister Ferenc Gyurcsány at a closed faction meeting (notorious for declarations such as "we were lying from dawn to dusk"), and due to the outbreak of the 2008 global economic crisis. This supports the conclusion on wide-spread system derogation drawn by Kelemen and colleagues (2014). By contrast, the political context was quite different in 2014 and in 2017, in which significantly higher levels of system justification were measured; this is evident not only the data reported on by Jost and Kende (2020), but also the 2014, 2016 and 2018 ESS rounds show much higher system justification than previous rounds. This is in line with the conclusion drawn by Jost and Kende (2020), who point out that although mean system justification remained below the scale midpoint, it is not extremely low. In the same vein, that the association between right-wing political orientation and system justification altered in 2010 can explain why the findings reported by Kelemen and colleagues (2014; Lönnqvist et al, 2019) and the findings reported on by Caricati (2019) and Jost and Kende (2020) allow for very different conclusions regarding the rigidity-of-the-right. As pointed out by Jost and Kende (2020), the fundamental change in political context was practically declared by Prime Minister Viktor Orbán in 2014, who, in a famous speech, expressed his intention to establish an illiberal nation state. Given that system justification is measured by items referring to "the Hungarian society", it can be easily be argued that completely different systems were referred to in the studies run before (Kelemen et al., 2014) and after (Jost and Kende., 2020) Fidesz victory.

The majority of system justification research has been conducted in the United States, and even non-US samples typically come from stable democracies (Osborne, Sengupta, \& Sibley, 2018). The findings by Kelemen and his colleagues (2014), the review by Jost and Cichocka (2014), and our findings based on the ESS data point to the same conclusion: system-justification in Central and Eastern Europe is the exception and not the rule. Even the findings by Jost and Kelemen (2020) show that the typical Central and Eastern European agrees with items assessing system justification only if these items also map onto individual and/or group interests. It could be that an autonomous system 


\section{POWER SYSTEM JUSTIFICATION RIGIDITY}

justification motive exists in stable democracies (for a review see Jost, 2019), but not in the Central and Eastern European region. People in this region could be habituated against 'systems', as systems in this context have historically been oppressors and conquerors. For instance, Hungary has a history of oppression since 1526, when the Ottoman Empire defeated the Hungarian army. After 150 years of Ottoman rule, the Habsburgs took over, after which Germany invaded the country in the second world war. After the war, the Soviet Union made Hungary its satellite state (László, 2014).

Some limitations warrant mention. Most importantly, it could be argued that system justification tendencies cannot be equated with satisfaction with and trust in the political system, which is what we actually measured. However, in defense of interpreting these measures as indicators of system justification, strong correlations have been reported on between these measures and more direct measures of system justification (Osborne et al, 2018; Tan, Liu, Hang, Zheng, \& Liang, 2016). Moreover, other work on system justification theory has employed these measures as indicators of system justification (see Caricati, 2019; Jost et al., 2003; Brandt, 2013), and also the originator of the theory (Jost and Kende, 2020) has recently cited research using these measures (Caricati, 2019) as supporting evidence in the present debate.

\section{Conclusion}

The most important conclusions of the present study are (1) that Hungarian society is generally characterized by system derogation, not system justification, (2) that right-wing political orientation is not always associated with system justification in Hungary, and left-wing political orientation is sometimes associated with system justification in Hungary, and (3) those who support the ruling party, be it left-wing or right-wing, will be the strongest supporters of the system.

\section{End Note}


POWER SYSTEM JUSTIFICATION RIGIDITY

1 - In 2002, personal trust in national institutions was measured with four items (trust in political parties was not measured).

Funding: The authors have no funding to disclose.

Compliance with Ethical Standards: All procedures performed in studies involving human participants were in accordance with the ethical standards of the institutional research committee and with the 1964 Helsinki Declaration and its later amendments or comparable ethical standards.

Conflict of interest: The authors declare that they have no conflict of interest.

\section{References}

Benczes, I. (2016). From goulash communism to goulash populism: The unwanted legacy of Hungarian reform socialism. Post-Communist Economies, 28, 146-166.

https://doi.org/10.1080/14631377.2015.1124557

Brandt, M.J. (2013). Do the disadvantaged legitimize the social system? A large-scale test of the status-legitimacy hypothesis. Journal of Personality and Social Psychology, 104(5), 765-785. https://doi.org/10.1037/a0031751

Caricati, L. (2019). Evidence of decreased system justification among extreme conservatives in non-American samples. The Journal of Social Psychology, 159(6), 725-745.

https://doi.org/10.1080/00224545.2019.1567455

Caricati, L., \& Owuamalam, C.K. (2020). System justification among the disadvantaged: A triadic social stratification perspective. Frontiers in Psychology.

https://doi.org/10.3389/fpsyg.2020.00040 
POWER SYSTEM JUSTIFICATION RIGIDITY

Cichocka, A., \& Jost, J.T. (2014). Stripped of illusions? Exploring system justification processes in capitalist and post-communist societies. International Journal of Psychology, 49(1), 6-29. https://doi.org/10.1002/ijop.12011

Conway, L.G., III, Houck, S.C., Gornick, L.J., \& Repke, M.A. (2018). Finding the Loch Ness monster: Left-wing authoritarianism in the United States. Political Psychology, 39(5), 1049-1067. https://doi.org/10.1111/pops.12470

European Social Survey (2002-2018). ESS rounds 1-9 (2002-2018). Retrieved from https://www.europeansocialsurvey.org/data/country.html?c=hungary

Federico, C. M., \& Malka, A. (2018). The Contingent, Contextual Nature of the Relationship Between Needs for Security and Certainty and Political Preferences: Evidence and Implications. Political Psychology, 39(S1), 3-48. https://doi.org/10.1111/pops.12477

Feldman, S., \& Johnston, C. (2014). Understanding the determinants of political ideology: Implications of structural complexity. Political Psychology,35(3), 337-358.

https://doi.org/10.1111/pops.12055

Jost, J.T. (2017). Ideological asymmetries and the essence of political psychology. Political Psychology, 38(2), 167-208. https://doi.org/10.1111/pops.12407

Jost, J.T. (2019). A quarter century of system justification theory: Questions, answers, criticisms, and societal applications. British Journal of Social Psychology, 58(2), 263-314. https://doi.org/10.1111/bjso.12297

Jost, J.T., Badaan, V., Goudarzi, S., Hoffarth, M. \& Mogami, M. (2019). The future of system justification theory. British Journal of Social Psychology, 58(2), 382-392.

https://doi.org/10.1111/bjso.12309 
POWER SYSTEM JUSTIFICATION RIGIDITY

Jost, J.T., Federico, C.M., \& Napier, J.L. (2009). Political ideology: Its structure, functions, and elective affinities. Annual Review of Psychology, 60, 307-337.

https://doi.org/10.1146/annurev.psych.60.110707.163600

Jost, J.T., \& Kende, A. (2020). Setting the record straight: System justification and rigidity-ofthe-right in contemporary Hungarian politics. International Journal of Psychology, 55(S1), 96-115. https://doi.org/10.1002/ijop.12631

Jost, J.T., \& Pelham, B.W., Sheldon, O., \& Sullivan, B.N. (2003). Social inequality and the reduction of ideological dissonance on behalf of the system: Evidence of enhanced system justification among the disadvantaged. European Journal of Social Psychology, 33(1), 13-6. https://doi.org/10.1002/ejsp.127

Kay, A.C., \& Jost, J.T. (2003). Complementary justice: Effects of "poor but happy" and "poor but honest" stereotype exemplars on system justification and implicit activation of the justice motive. Journal of Personality and Social Psychology, 85(5), 823-837. https://doi.org/10.1037/0022$\underline{3514.85 .5 .823}$

Kelemen, L., Szabó, Z.P., Mészáros, N.Z., László, J., \& Forgas, J.P. (2014). Social cognition and democracy: The relationship between system justification, just world beliefs, authoritarianism, need for closure, and need for cognition in Hungary. Journal of Social and Political Psychology, 2(1), 197219. https://doi.org/10.5964/jspp.v2i1.208

László, J. (2014). Historical tales and national identity. An introduction to narrative social psychology. Routledge.

Lönnqvist, J-E., Szabó, Z.P., \& Kelemen, L. (2019). Rigidity of the far-right? Motivated social cognition in a nationally representative sample of Hungarians on the eve of the far-right breakthrough in the 2010 elections. International Journal of Psychology, 54(3), 292-296. https://doi.org/10.1002/ijop.12497 
POWER SYSTEM JUSTIFICATION RIGIDITY

Malka, A., \& Soto, C. J. (2015). Rigidity of the economic right? Menu-independent and menudependent influences of psychological dispositions on political attitudes. Current Directions in Psychological Science, 24(2), 137-142. https://doi.org/10.1177/0963721414556340

Malka, A., Soto, C. J., Inzlicht, M., \& Lelkes, Y. (2014). Do needs for security and certainty predict cultural and economic conservatism? A cross-national analysis. Journal of Personality and Social Psychology, 106(6), 1031-1051. https://doi.org/10.1037/a0036170

Osborne, D., Jost, J.T., Becker, J.C., Badaan, V., \& Sibley, C.G. (2018). Protesting to challenge or defend the system? A system justification perspective on collective action. European Journal of Social Psychology, 49(2), 244-269. https://doi.org/10.1002/ejsp.2522

Osborne, D., Sengupta, N., \& Sibley, C.G. (2018). System justification theory at 25: Evaluating a paradigm shift in psychology and looking towards the future. British Journal of Social Psychology, 58(2), 340-361. https://doi.org/10.1111/bjso.12302

Owuamalam, C.K., Rubin, M., \& Spears, R. (2016). The system justification conundrum: Reexamining the cognitive dissonance basis for system justification. Frontiers in Psychology. https://doi.org/10.3389/fpsyg.2016.01889

Owuamalam, C.K., Rubin, M., \& Spears, R. (2018). A critical review of the (un)conscious basis for system-supporting attitudes of the disadvantaged. Social and Personality Psychology Compass, 12(11), e12419. https://doi.org/10.1111/spc3.12419

Owuamalam, C.K., Rubin, M., \& Spears, R. (2019a). Is a system motive really necessary to explain the system justification effect? A response to Jost (2019) and Jost, Badaan, Goudarzi, Hoffarth, and Mogami (2019). British Journal of Social Psychology, 58(2), 393-409. $\underline{\text { https://doi.org/10.1111/bjso.12323 }}$

Owuamalam, C.K., Rubin, M., \& Spears, R. (2019b). Revisiting 25 years of system justification motivation explanation for system justification from the perspective of social identity model of 
POWER SYSTEM JUSTIFICATION RIGIDITY

system attitudes. British Journal of Social Psychology, 58(2), 363-381.

https://doi.org/10.1111/bjso.12285

Tan, X., Liu, L., Huang, Z., Zheng, W., \& Liang, Y. (2016). The effects of general system justification on corruption perception and intent. Frontiers in Psychology, 26(7), 1107. https://doi.org/10.3389/fpsyg.2016.01107

van der Toorn, J., Feinberg, M., Jost, J.T., Kay, A.C., Tyler, T.R., Willer, R., \& Wilmuth, C. (2015). A sense of powerlessness fosters system justification: Implications for the legitimation of authority, hierarchy, and government. Political Psychology, 36(1), 93-110.

https://doi.org/10.1111/pops.12183

Zmigrod, L., Rentfrow, P.J., \& Robbins, T.W. (2019). The partisan mind: Is extreme political partisanship related to cognitive inflexibility? Journal of Experimental Psychology: General, 149(3), 407-418.https://doi.org/10.1037/xge0000661 
SYSTEM JUSTIFICATION RIGIDITY RIGHT

TABLE 1.

Main demographic characteristics of the samples for each round.

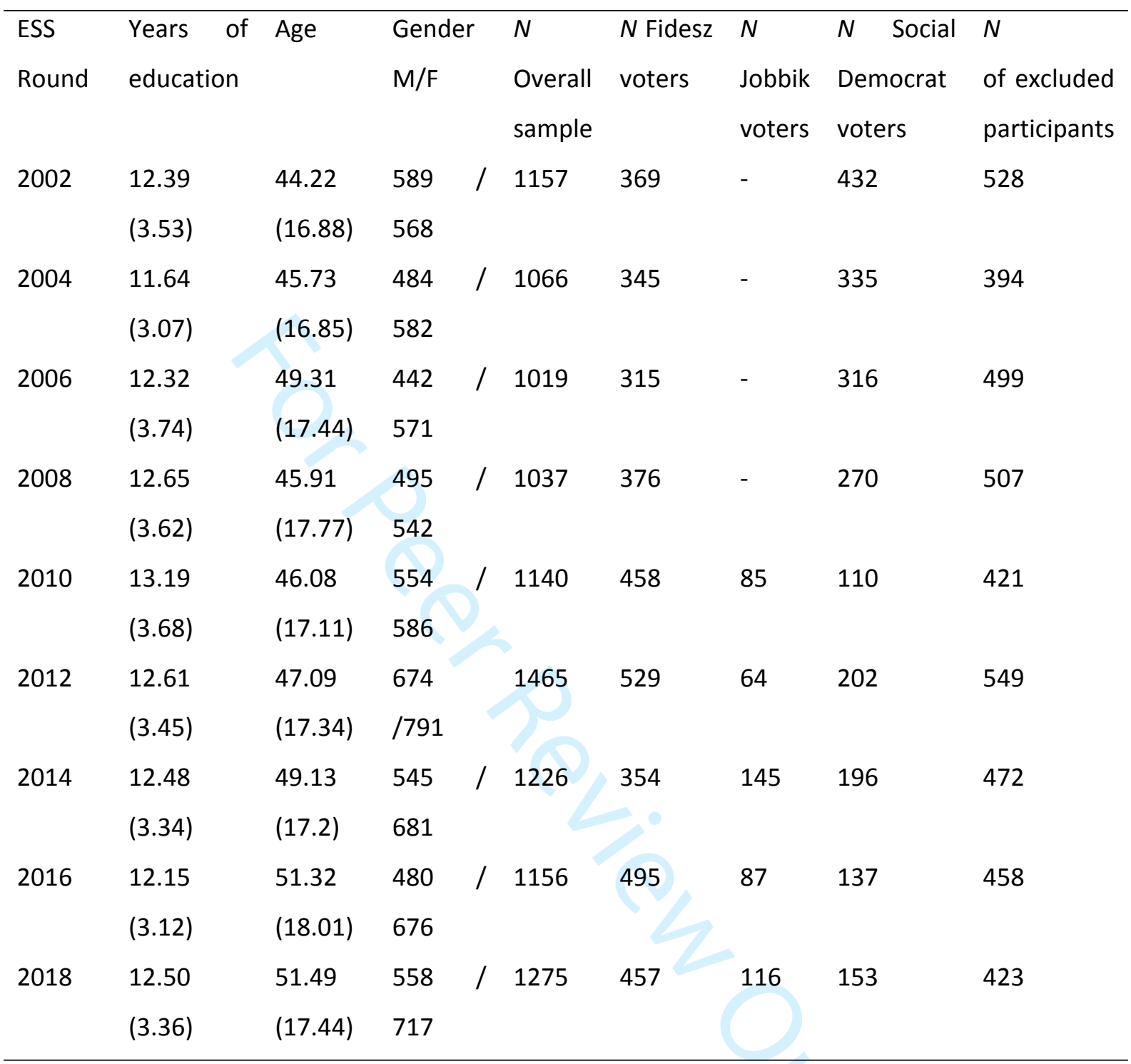

Note. Excluded participants had missing values for either political orientation and/or the system justification items. Between 2002 and 2014, the "Social democrats" group included only MSZP voters. In 2014, MSZP participated in the national election as a part of a coalition, named "Government changers", including other leftist parties. Accordingly, ESS used the "Government changers" category in the 2014 and 2016 rounds when they assessed last voting. In 2016, we considered MSZP voters, and DK (Democratic Coalition) voters as "Social democrats". DK was originally formed as a fraction of the MSZP and became a separate party in 2011. Jobbik first participated in the national elections in 2010. 
TABLE 2.

Descriptive statistics for system justification according to political party preference.

\begin{tabular}{|c|c|c|c|c|c|c|c|c|}
\hline ESS round & Satisfaction & Satisfaction & Satisfaction & Satisfaction & Trust Overall & Trust & Trust & Trust \\
\hline & Overall sample & Fidesz & Jobbik & Social democrats & sample & Fidesz & Jobbik & Social democrats \\
\hline 2002 & $4.44(1.56)$ & $4.36(1.57)$ & - & $4.50(1.54)$ & $4.82(2.05)$ & 4.64 (1.99) & - & $5.03(2.05)$ \\
\hline 2004 & $3.82(1.66)$ & $3.53(1.61)$ & - & $4.08(1.64)$ & $3.88(1.87)$ & $3.83(1.80)$ & - & $4.14(1.86)$ \\
\hline 2006 & 3.49 (1.79) & 2.84 (1.67) & . & 4.17 (1.79) & 3.70 (1.97) & $3.26(1.77)$ & - & 4.35 (2.07) \\
\hline 2008 & $3.31(1.73)$ & $2.85(1.59)$ & - & 3.78 (1.83) & $3.01(1.88)$ & $2.69(1.80)$ & - & 3.34 (2.03) \\
\hline 2010 & $4.08(1.58)$ & $4.50(1.51)$ & $3.54(1.56)$ & $3.84(1.52)$ & $4.16(2.03)$ & 4.96 (1.99) & $3.21(2.03)$ & $4.02(1.83)$ \\
\hline 2012 & $4.26(1.86)$ & 4.79 (1.83) & $4.02(1.72)$ & $3.35(1.80)$ & $4.13(2.17)$ & $4.83(2.21)$ & 3.90 (1.95) & 3.59 (1.89) \\
\hline 2014 & 4.02 (1.96) & $5.06(1.82)$ & 3.35 (1.88) & $3.53(1.93)$ & 4.09 (2.17) & $5.21(2.20)$ & $3.63(2.10)$ & 3.83 (1.93) \\
\hline 2016 & $4.80(1.83)$ & $5.76(1.56)$ & $3.97(1.76)$ & $3.49(1.55)$ & $4.96(2.04)$ & $5.81(1.96)$ & $4.29(2.00)$ & $4.23(1.76)$ \\
\hline 2018 & $4.55(2.10)$ & $5.87(1.81)$ & 3.15 (1.76) & $3.22(1.52)$ & $5.04(2.04)$ & $6.19(1.77)$ & $3.96(1.80)$ & $4.17(1.64)$ \\
\hline
\end{tabular}

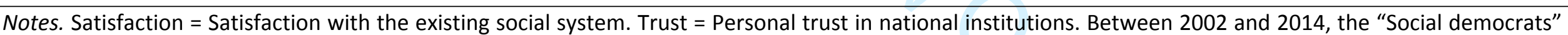

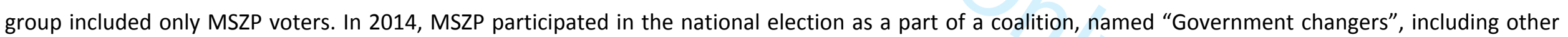

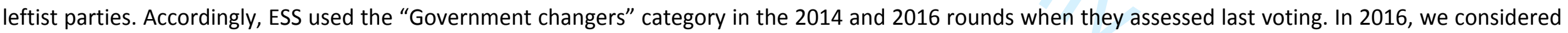

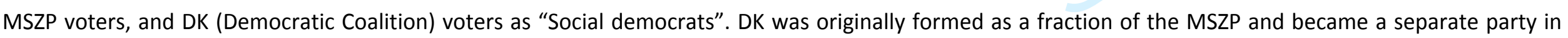
2011. Jobbik first participated in the national elections in 2010. 
TABLE 3.

Correlations between left-right political self-placement and system justification in Hungary between 2002 and 2018.

\begin{tabular}{lll}
\hline $\begin{array}{l}\text { ESS round / Left-right self- } \\
\text { placement }\end{array}$ & $\begin{array}{l}\text { Satisfaction with the existing } \\
\text { system }\end{array}$ & $\begin{array}{l}\text { Personal trust in } \\
\text { institutions }\end{array}$ \\
2002 & $-0.045, p=.123$ & $-0.083, p=.004$ \\
2004 & $-0.11, p<.001$ & $-.02, p=.53$ \\
2006 & $-0.36, p<.001$ & $-0.29, p<.001$ \\
2008 & $-0.24, p<.001$ & $-0.14, p<.001$ \\
2010 & $0.18, p<.001$ & $0.22, p<.001$ \\
2012 & $0.41, p<.001$ & $0.33, p<.001$ \\
2014 & $0.28, p<.001$ & $0.30, p<.001$ \\
2016 & $0.42, p<.001$ & $0.35, p<.001$ \\
2018 & $0.42, p<.001$ & $0.34, p<.001$
\end{tabular}

